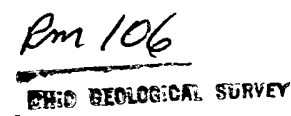
HOV $\$ 9$ STo

\title{
Marine Gold Placers Along the Gulf of Alaska Margin
}

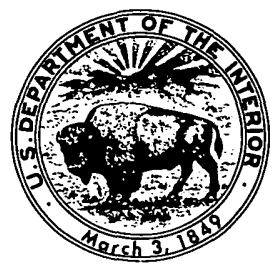

QE 75

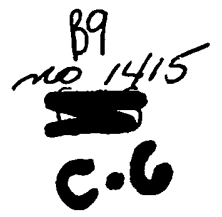




\section{Marine Gold Placers Along the Gulf of Alaska Margin}

By ERK REIMNITZ and GEORGE PLAFKER

GE O L O I C A L S U R VEY B U L L E T I N 1415

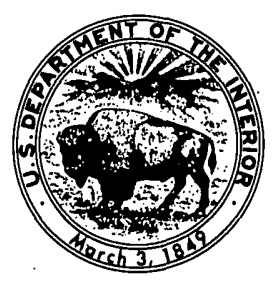




\section{UNITED STATES DEPARTMENT OF THE INTERIOR}

THOMAS S. KLEPPE, Secretary

\section{GEOLOGICAL SURVEY}

V. E. McKelvey, Director

Library of Congress catalog-card No. 76-608199

For sale by the Superintendent of Documents, U. S. Government Printing Office Washington, D. C. 20402

Stock Number 024-001-02850-6 


\section{CONTENTS}

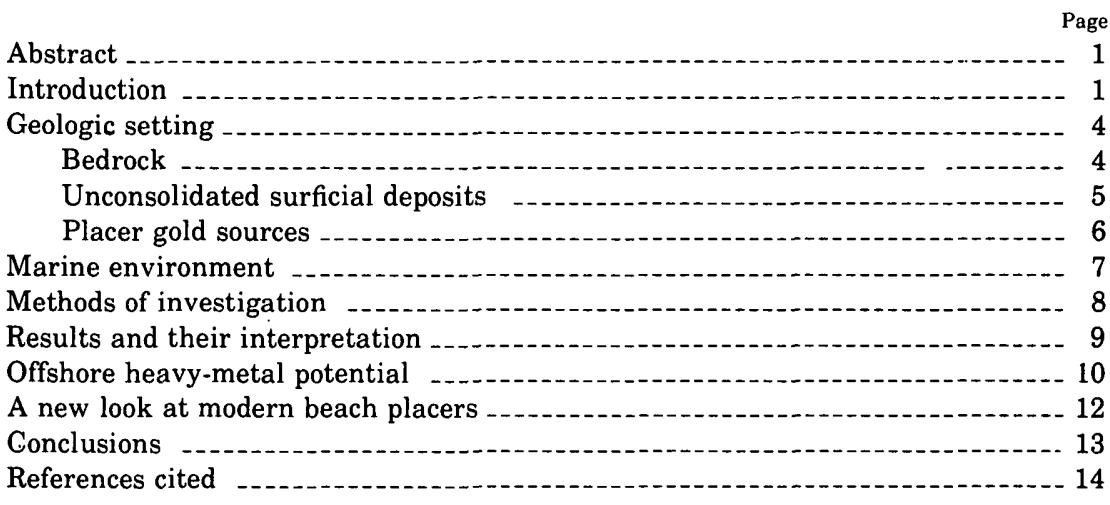

\section{ILLUSTRATIONS}

Plate 1. Generalized geology and placer gold sampling localities, 


\title{
MARINE GOLD PLACERS ALONG THE GULF OF ALASKA MARGIN
}

\author{
By Erk Reimnitz and George Plafker
}

\begin{abstract}
Fifty-five beach samples, collected along the Gulf of Alaska between Dry Bay and Prince William Sound, were analyzed for their gold content in order (1) to gather information on gold placers in areas that have not been mined, such as the Copper River Delta, (2) to gather information needed in the search for placers on the adjacent continental shelf, and (3) to learn more about the occurrence and behavior of modern beach placers with a view toward enhancing their economic potential.

In general, the beaches contain very little gold, but certain areas along the Copper River Delta contain as much as other areas to the east that have been productive, and on a unit-length basis one of the barrier islands appears to contain more dark sand than most other areas. More detailed study of the heavy-mineral distribution on the Copper River Delta seems warranted.

Much of the gold on the beaches appears to have been concentrated from the Yakataga Formation. This formation also underlies much of the adjacent continental shelf where it has been truncated. The potential for finding auriferous submarine beach or relict nearshore deposits therefore is great.

Available evidence suggests that gold is being lost from the beaches to the offshore area. Therefore, gold may be concentrated in favorable nearshore locations at present and may also have formed in such areas in the past. Thus, the search for economic placer deposits on continental shelves should not be restricted to relict beach and residual deposits.

Heavy-mineral concentrates with associated gold on the beaches of the Gulf of Alaska generally are small in volume and are short-lived owing to high rates of reworking, redistribution, and longshore transport. For these reasons, the possibility should be investigated of enhancing the economic potential of future placer mining operations by using fixed engineering structures that modify the surf-zone environment, thereby concentrating gold and other valuable heavy constituents.
\end{abstract}

\section{INTRODUCTION}

In the summer of 1969 a five-day reconnaissance survey by helicopter covered about $400 \mathrm{~km}$ of coastline along the Gulf of Alaska Coast between Hinchinbrook Island and Dry Bay (fig. 1). Fifty-five samples of beach material were collected during this survey and later were analyzed for gold. The purpose of the investigation is severalfold: (1) to compare the gold content of black-sand-bearing beaches in the Copper River Delta area with those in the Yakataga, Yakutat, and other areas where beach placers have been mined; (2) to apply this information to the adjacent continental shelf region, with a view to 


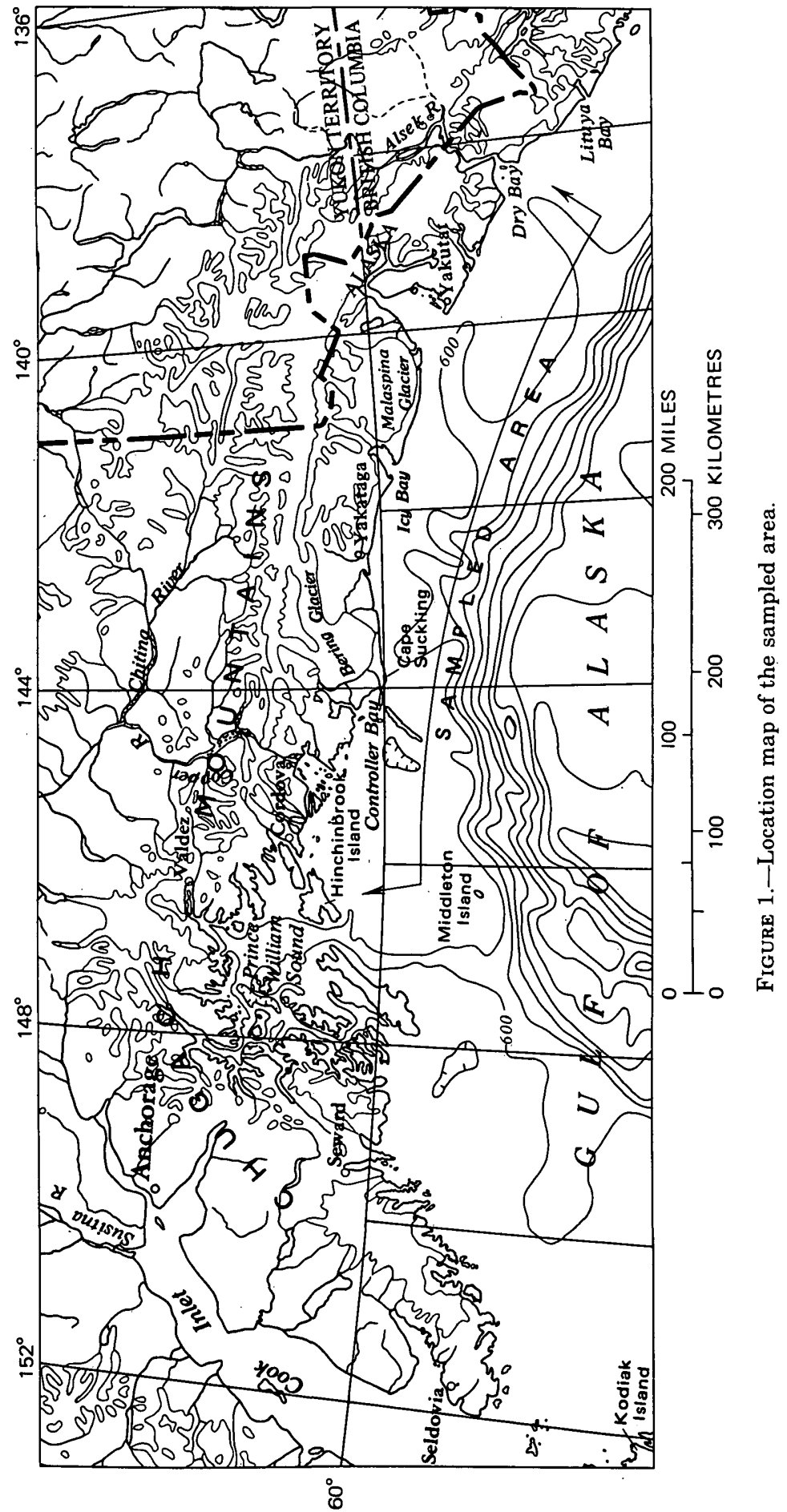


outlining offshore areas in which future exploration might be profitable; and (3) to obtain data that might be useful for the development of better beach-mining methods.

The beaches in the Lituya Bay area were mined sporadically for gold by the Russians before 1867 and since 1894 by the Americans. In 1896, 150-200 men were engaged in these operations (Thomas and Berryhill, 1962). In the Yakutat area, gold was first noted in beaches in 1886 or 1887 (Tarr and Butler, 1909) and was mined on a small scale continuously for several decades and intermittently since. In the Yakataga district, gold was first found in 1897 or 1898, and about 40 men worked primarily along a $6-\mathrm{km}$ (3.8 miles) stretch of beach east of Cape Yakataga in 1903 (Maddren, 1914). Intermittent smallscale placer mining has continued in this area to the present day. Small-scale placer mining has also been conducted on the southwest tip of Middleton Island (Brooks, 1913, p. 43) and on certain stretches of beaches on Kodiak Island around the turn of the century (Maddren, 1919). Overall production estimates are highest for the Yakataga district.

Beach-placer gold production from the Gulf of Alaska [From Cobb, 1972]

\begin{tabular}{l} 
Area \\
\hline $\begin{array}{l}\text { Lituya and Yakutat districts } \\
\text { Yakataga district } \\
\text { Middleton Island } \\
\text { Kodiak Island (west coast) } \\
\text { Homer district (mainly from Anchorage Point) }\end{array}$ (in ounces) \\
\hline
\end{tabular}

During the last 15 years, private companies have investigated certain beach areas within the Lituya district and near Yakataga for gold and heavy minerals, but no production has resulted to date. The U.S. Geological Survey made a reconnaissance study of radioactive materials in the Yakataga beach placers in 1947-49 (Moxham, 1952), and in 1957 and 1958 the U.S. Bureau of Mines carried out extensive auger drilling to outline heavy-mineral concentrations in the area between Cape Suckling and Icy Point in southeastern Alaska (Thomas and Berryhill, 1962). Unfortunately these data are unsuitable for compilation of gold values for comparison. In 1967, the University of Alaska and the U.S. Geological Survey, carried out seismic-reflection surveys and bottom-sampling in an unsuccessful search for gold concentrations in Yakutat Bay (Wright, 1969) and on the continental shelf between Bering Glacier and the Dangerous River (R. von Huene, oral commun., 1969). Bottom samples generally contained less than a few parts per billion gold. In addition, a number of stream-sediment samples and one beach sample in the report area 
were analyzed for gold (MacKevett and Plafker, 1970). The beach sample, from a black-sand concentrate near the mouth of Situk River, contained $0.5 \mathrm{ppm}$ gold. Fifty-two samples, both from modern and ancient beaches in the Cape Yakataga region, were analyzed for gold and other minerals by Cook (1969).

Along much of the coast of the Gulf of Alaska, sand concentrates of heavy minerals (often referred to as "ruby sand" because of their reddish color) occur in patches as relatively thin layers on the modern beach near the high-tide line and behind storm berms near the base of the sand dunes or sea cliffs. They commonly have a high garnet, magnetite, and ilmenite content and generally contain trace amounts of rutile, zircon, chromite, and also fine gold. Minor amounts of platinum have been recovered from beach placers in the Yakutat and Lituya districts and on southwestern Kodiak Island. The highest concentrations of gold occur along a stretch of beach west of Cape Yakataga, along short beaches at the west side of Yakutat Bay, and along the open coast in the Yakutat area. None of these areas, however, can support continuous, profitable mining operations at present. The gold grains are so small that many are lost with the traditional methods of concentration.

The volume of beach material with higher concentrations of heavy minerals generally is small, and the accumulations are transient. The concentrations occur in the upper, active parts of beaches, principally after winter storms, and often the heavy minerals are reworked or covered with fresh deposits as the beach changes. At least one example of the short-lived nature of economic concentrations has been described by Maddren (1919); he reported that deposits formed by one storm often could not be recovered before the next storm arrived. In this respect, conditions in the report area are very similar. Moreover, the rate of supply of fresh materials and winnowing within the marine environment in the report area is such that small-scale mining operations would deplete a particular beach in a few years.

Techniques used in the past in the offshore exploration for gold did not serve to delineate the most likely ancient or modern settings for economic concentrations. Widely spaced surface samples show only very low gold values associated with relict gravel or nearshore sand. In this report we will consider some new concepts and areas for future exploration.

\section{GEOLOGIC SETTING}

\section{BEDROCK}

The rocks exposed in and adjacent to the report area may be broadly divided into three major sequences that are separated by unconformities and that differ considerably in age, lithology, degree 
of deformation, and topographic expression (Miller, 1961a-e; Plafker, 1967, 1971). From oldest to youngest, these sequences are as follows: (1) A crystalline complex consisting of a diverse assemblage of late Paleozoic(?) and Mesozoic mica schist, volcanic rocks and marble metamorphosed to the high-grade greenschist to amphibolite facies. (2) A slightly metamorphosed, eugeosynclinal sequence of late Mesozoic age (Yakutat and Valdez Groups) that is metamorphosed to zeolite or epidote amphibolite facies and is characterized by abundant volcaniclastic detritus, intense deformation, and tectonically intermixed rock fragments and blocks of widely diverse origin and age (melange). (3) Mildly to strongly deformed continental and marine sedimentary rocks at least $12,000 \mathrm{~m}(40,000 \mathrm{ft})$ thick that range in age from Paleocene through Pleistocene. The Cenozoic sequence is further broadly divisible into (a) a lower unit of well-indurated, strongly deformed marine and continental coal-bearing rocks of Paleocene through early Oligocene age; (b) an overlying unit of lessdeformed and less-indurated marine clastic and volcanic rocks of Oligocene and early Miocene age, and (c) a thick upper unit of slightly to moderately deformed marine clastic rocks characterized by abundant glacial detritus (Yakataga Formation) that ranges in age from middle Miocene through early Pleistocene.

The two older bedded sequences are intruded by numerous quartz diorite, granodiorite, and adamellite plutons that range in age from middle Jurassic to middle Tertiary. In addition, three late Mesozoic plutons of distinctive layered mafic and ultramafic rocks occur within the crystalline sequence in the Fairweather Range (Plafker and MacKevett, 1970). Numerous small aplite and pegmatite dikes are associated with some of the granitic plutons, and the plutons locally have extensive aureoles of migmatite or hornfels. In addition, widely scattered smaller intrusive bodies of Tertiary age cut both the preTertiary and Tertiary sequences. These include lamprophyric to diabasic mafic dikes and plugs and rare stocks, plugs, and dikes of quartz porphyry.

The Chugach-Saint Elias and Fairweather fault systems, which strike roughly parallel to the Gulf of Alaska coast, form important structural boundaries between geologically and physiographically distinctive terranes. In general, the rugged mountainous terrane north of these faults is underlain by crystalline igneous and metamorphic rocks, whereas the adjacent foothills and coastal-plain belt to the south is underlain largely by Cretaceous and Cenozoic bedded rocks with associated small igneous intrusive bodies.

\section{UNCONSOLIDATED SURFICIAL DEPOSITS}

The Tertiary and older bedrock formations around the Gulf of 
Alaska are overlain unconformably, at most places with marked angular discordance, by flat-lying unconsolidated surficial deposits that are largely, if not entirely, of Holocene age. These deposits were formed in both marine and terrestrial environments and are thickest and most extensive on the coastal lowland and on some elevated marine terraces (fig. 2). They have been subdivided and described by Miller (1961a-e) and other geologists. In the coastal region, the major types, classified according to lithologic character and origin, are (1) well-sorted sand and gravel formed at or near the present beach and on former beaches, including strand lines elevated by Holocene tectonic uplift; (2) well-sorted dune sand on or near the present or former beaches; (3) interbedded mud and sand containing much organic debris, which were formed on tidal flats, in bays or lagoons, and in clear lakes and swamps; (4) interbedded mud and poorly sorted to moderately well-sorted sand and gravel, which were formed on the flood plains or fans of streams on the outwash aprons of glaciers and in glacial lakes; and (5) till formed at or near the margins of glaciers, including terminal and ground moraine and ice-rafted deposits.

The thickness of the unconsolidated deposits on the coastal lowland and along the raised beach ridges is not well known. Data from oilcompany exploratory wells and seismic profiling indicate that the unconsolidated deposits are commonly up to a few hundred metres (several hundred feet) thick. Marine deposits on the highest terrace (elevation up to $230 \mathrm{~m}$ (750 ft)) in the Lituya district, between Lituya Bay and Sea Otter Creek, are estimated to be 15-30 m thick (50-100 $\mathrm{ft}$ ), and the deposits on an elevated terrace at the northwestern margin of the La Perouse Glacier are $3 \mathrm{~m}(10 \mathrm{ft})$ thick. In the Yakataga district, surficial deposits on elevated marine terraces between Icy Bay and Cape Yakataga range in thickness from less than a meter (a

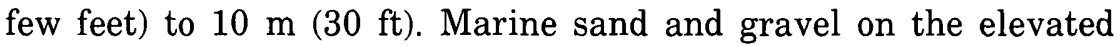
terraces in the Katalla district are of an uncertain thickness; where exposed in coastal cliffs, these deposits are generally less than $3 \mathrm{~m} \mathrm{(10}$ ft) thick. Offshore Holocene deltaic deposits on the Copper River Delta are up to $180 \mathrm{~m}(600 \mathrm{ft})$ thick (Reimnitz, 1966). Stratified marine terrace deposits on Middleton Island range in thickness from

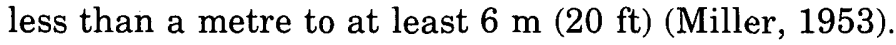

\section{PLACER GOLD SOURCES}

The original source of placer gold and other valuable heavy minerals in the beaches around the Gulf of Alaska is undoubtedly the igneous rocks and related alteration zones in the coastal (and possibly interior) mountains. There are no operative lode-gold mines in this region. Numerous gold lodes occur throughout the Chugach and Kenai Mountains. Gold was produced from mines along the north 
flank of the Chugach Mountains, in northern Prince William Sound, and in the area east of Cordova between about 1910 and 1940. It generally occurs associated with quartz veins cutting graywacke, argillite, and greenstone of the late Mesozoic Valdez Group and early Tertiary Orca Group (Moffit, 1954, p. 302-307).

A geochemical reconnaissance of parts of the Yakutat and Malaspina districts showed small amounts of gold in a few bedrock samples (MacKevett and Plafker, 1970, p. 17). The richest of these contained 0.08 parts per million gold and were from narrow quartz veins that cut metamorphic rocks near the Fairweather fault and from an altered zone in quartz diorite. In the Lituya district the ultramafic and mafic plutons of the Fairweather Range, which locally contain significant amounts of ilmenite, magnetite, platinum, and other heavy minerals, are probably the source of much of the placer beach deposits in the Lituya and Yakutat districts (Plafker and MacKevett, 1970).

Some of the placer gold and other valuable minerals on the present beaches and in the subparallel emergent shorelines have apparently been derived directly from mineralized bedrock in the mountains and transported to the coast by glaciers and (or) streams. Gold of the Copper River Delta is in this category; some of the heavy minerals in beach placers along the southern margins of the Malaspina Glacier and on the Yakutat Foreland may also have been similarly derived. Much of the placer gold, however, was involved in one or more cycles of deposition in the clastic Cenozoic formations of the region before being reworked and concentrated in the beach deposits. Gold is probably distributed generally at random in the marine-glacial deposits of the late Cenozoic Yakataga Formation and, possibly, in other parts of the thick sequence of Cenozoic strata exposed along the Gulf of Alaska margin. The prevailing fine size of the placer gold and its occurrence on beaches at Middleton Island, near Lituya Bay, and at Cape Yakataga in outcrop areas of the Yakataga Formation suggest that in these localities it is being reworked from that formation. Significantly, the only possible source for the placer gold found on the beaches at Middleton Island is the Yakataga Formation, which underlies the entire island and much of the shelf. A detailed geochemical sampling program of the different types of sedimentary rock in the Yakataga Formation would be required to determine how and where the gold occurs in the Cenozoic sequence.

\section{MARINE ENVIRONMENT}

The beaches that were sampled during this investigation for the most part are exposed to the full force of storm waves generated over the Gulf of Alaska. The storms, most common and severe from October through February, blow from a southeasterly to easterly direc- 
tion (Reimnitz, 1966). Longshore transport therefore is northwesterly to westerly, and this trend is reflected in the configuration of barrier islands and sand spits. The tidal range is great, reaching extremes of over $6 \mathrm{~m}(20 \mathrm{ft})$, causing strong currents around tidal inlets, river mouths, and bay entrances. For these reasons, the rate of reworking of material supplied to the sea is fast, and delta fronts are straight, blending into the general shoreline.

The beaches in most areas consist of well-sorted medium-grained sand. At the Copper River Delta, where rates of sediment supply are high, the modern sand extends offshore to a depth of $50 \mathrm{~m}(165 \mathrm{ft})$ (Reimnitz, 1966). This great depth range of sand probably is common around the Gulf of Alaska and is related to reworking of material by storm waves and currents.

Pebbles, cobbles, or boulders within the beach prism occur only on short stretches of coast bordered by cliffs exposing Quaternary or older rocks, in areas where morainal material is reworked by the sea, and in the Sitkagi Bluffs region at the foot of the Malaspina Glacier. Elsewhere, material coarser than sand size is uncommon.

\section{METHODS OF INVESTIGATION}

The beaches from Hinchinbrook Island at the west to Dry Bay at the east, were sampled at 55 locations (pl. 1) within a period of 5 days, using a helicopter for transportation. Most samples were collected from the beach surface, either near the high-tide line, on the berm, or just landward of the berm, where concentrations are highest. Conspicuous layers of dark minerals were sampled preferentially. Sample locations in any particular area were chosen to avoid relatively unwinnowed areas of accretion, as for example on the downdrift end of barrier spits where low heavy-mineral contents are expected. Only a few samples are exceptions to the general sampling approach used. Thus, sample 22 at Cape Suckling, was collected from a small pocket of sand on a bedrock surface exposed at low tide seaward of the beach. Sample 20 near the above station was collected from the top of a stream-dissected soil horizon forming the base of a beach that became inactive after the 1964 uplift associated with the Alaska earthquake. Sample 40 consists of a noticeable concentration of dark minerals 40 $\mathrm{cm}(1.3 \mathrm{ft})$ below the beach surface; sample 41 is from a thin, highly concentrated surface layer at the same location on Black Sand Spit. Sample 30 represents dune sand from Cape Yakataga, which is gold bearing according to Charlie Bilderback (oral commun., 1969), a prospector of Yakataga.

Sample locations are closely spaced in the Yakataga and Yakutat areas, which have been productive, and along the beaches of the Copper River Delta where the senior author noted dark-mineral con- 
centrations during a study of the delta (Reimnitz, 1966). Pete Dahl Bar is notable among the barrier islands of the Copper River Delta. The distribution of dark sand, as observed from the air, was widespread along the upper beach and also on the flat part of this barrier island behind the beach where it is not covered by sand dunes. Digging at various places near the three sample localities on this island revealed that the relatively high concentration of dark minerals was not restricted to a thin surface layer but extended to a depth of at least a metre ( $3 \mathrm{ft})$ in some areas. A semiquantitative spectrographic analysis of a beach sample collected in previous work near the east end of this island showed high concentrations of $\mathrm{Fe}, \mathrm{Ti}, \mathrm{Mn}, \mathrm{Cr}, \mathrm{Ni}, \mathrm{V}$, and $\mathrm{Zr}$; this heavy-mineral assemblage is similar to that of other beaches studied previously along the Gulf of Alaska coast.

Between 2 and $8 \mathrm{~kg}$ (4.4 and 17.6 pounds) of material from each station was submitted for analysis. The analyses, by atomicabsorption techniques, were done by Kam Leong, U.S. Geological Survey, Menlo Park, Calif. In view of the small particle size of the gold in this area, the sample sizes probably were sufficient to fulfill the requirements for obtaining representative results, dictated by the particle sparsity effect (Clifton and others, 1969). For analysis, bulk samples were split into about six portions of about $700 \mathrm{~g}$ (1.5 pounds) each, small enough to be handled by the methods used. Five samples were sized before analysis; the gold in these was found primarily in the smaller than $125 \mu$ m fractions. This fact and the comparable gold values obtained for the different splits of each sample indicate that the gold values shown are fairly representative for the samples submitted.

\section{RESULTS AND THEIR INTERPRETATION}

The analytical results are shown on plate 1 . Generally gold values are very low. The highest values east of the Copper River with a maximum of $1.87 \mathrm{ppm}$ are from thin layers of "ruby sand" with limited areal extent at Situk (42), east of Sitkagi Bluffs (33), and east of the mouth of the White River (51). A small "ruby sand" sample collected in 1967 at Situk contained $0.5 \mathrm{ppm}$ gold (Plafker and MacKevett, 1970, p. L7), and another sample (69 Apr 108C) collected by Plafker in 1969 from near locality 33 contained $16 \mathrm{ppm}$. A sample with a pronounced concentration of "ruby sand" (41) from Black Sand Spit, however, contained very little gold. On the Copper River Delta, samples from two of the barrier islands were relatively high in gold. Sample 12, with $0.24 \mathrm{ppm}$ gold, is from the east end of Grass Island on the upper beach face, where no obvious concentrations of heavy minerals were noted.

Sample 16, with $0.25 \mathrm{ppm}$ gold, is from a 5-cm-thick surface layer 
with a notable concentration of dark minerals at the west end of Pete Dahl Bar. The other two samples from this barrier island contained only a trace of gold.

The potentially richest sand was sampled at each location throughout the area investigated, yet all the samples contained only small quantities of gold. The generally low gold-content probably relates in part to physical conditions; there were no large storms just prior to the fieldwork, and the ocean was calm during the period of sampling. Thus the beaches had steep foreshores and were well nourished with light-mineral constituents, and heavy minerals were sparsely disseminated. The uniformity of conditions that prevailed all along the coast during the fieldwork allows a comparison to be made between regions in which much prior work has been done and the barrier islands of the Copper River Delta which had not previously been sampled for their dark sand content.

In two localities, the beaches of the Copper River Delta have as much gold as beaches that have been mined. Furthermore, Pete Dahl Bar appears to contain other heavy minerals in concentrations similar to those reported for the Yakataga area, and these in the future might also be of economic interest. Most important, however, is that the volume of material containing heavy minerals on this island appears to be much larger than that of a similar stretch of beach in the Yakataga area.

The low gold values in samples taken east of the delta indicate that the heavy minerals of Pete Dahl Bar are not supplied by littoral drift from the east but rather from the Copper River drainage basin. Prior to the shift in dominant river discharge to a more easterly position, as a result of uplift associated with the great earthquake of 1964, Pete Dahl Bar bordered the tidal inlet that carried the principal Copper River discharge (Reimnitz, 1966). If a causative relationship exists between position of river discharge and the location where heavy minerals concentrate, Grass Island Bar, where samples No. 12 and 13 were collected, may presently be the area of maximum heavy mineral accumulation. It is likely that earlier, similar deposits have been incorporated into the wedge of delta sediments that accumulated during the last 6,000 years (Reimnitz, 1966).

\section{OFFSHORE HEAVY-METAL POTENTIAL.}

Shelf areas that are bordered by beaches containing heavy-metal accumulations are of interest for their future economic potential, even though they might not be profitably mined at present. Exploration has identified areas of interest on the continental shelf bordering Nome (Nelson and Hopkins, 1969). Similarly, possible heavy-metal 
accumulations have been identified on the shelf of northern California and Oregon (Kulm and others, 1968; Clifton, 1968; Moore and Silver, 1968). In the Gulf of Alaska, fjords and other embayments are unlikely sites for economic concentrations of heavy minerals because their sediment accumulated rapidly and with virtually no sorting (Reimnitz and others, 1970; Wright, 1969). In contrast, much of the open shelf in this part of the Gulf of Alaska is an erosional surface with little or no Holocene sediment cover and might well warrant future studies. R. von Huene (oral commun., 1969), in his reconnaissance of the shelf seaward of Yakataga and Yakutat, did not locate any areas of economic interest; but he did discover lag gravel in the Fairweather Ground area that contained trace amounts of gold and nearshore sand with considerable heavy mineral concentrations and traces of gold.

Wherever lag deposits unconformably overlie the Yakataga Formation, the probably source of much of the placer gold along the coast, the likelihood of finding heavy-metal concentrations should be good. One such area is Tarr Bank, a broad topographic high between Middleton Island and the Copper River Delta. Deformed strata of the Yakataga Formation lithologically similar to those constituting Middleton Island, although probably younger, are truncated by the bank top, and a thick layer of sediment has been removed by erosion (Reimnitz, 1966). High-resolution seismic records showed that the surface of the bank may be very similar to the flat top of Middleton Island; individual strata crop out in small-scale relief on the sea floor, and the erosional products have been transported northward and deposited in foreset beds that dip landward away from the bank (Reimnitz, 1966). Small lenses of Holocene sediment occur locally on the bank. Tarr Bank apparently has been affected by currents, waves, and possibly also by drifting ice in the recent past when the water depth was shallower than today (Reimnitz, 1966). The nature of the Holocene material found in shallow depressions on the bank top and above the northern flank is poorly known. But the possibility of finding lag deposits and relict beach and nearshore-sand deposits on the bank, or coarse granular erosional debris north of the bank, is good. Since the source for such deposits is probably the Yakataga Formation, the chances of finding concentrations of heavy minerals and of gold in them should be investigated.

Tarr Bank apparently is not the only area in this part of the Gulf of Alaska in which a topographic and structural high exposing the Yakataga Formation has been subjected to shallow-water reworking. Future exploratory work in these regions might well be fruitful. High-resolution seismic profiling and magnetometer surveys should be used to delineate regions with highest mineral potential. 


\section{A NEW LOOK AT MODERN BEACH PLACERS}

A number of factors, which have been described earlier, and which probably are not unique to the beaches of the Gulf of Alaska, have made small-scale placer mining operations in the area difficult if not uneconomical. The transient nature and small volume of beach sand with high gold concentrations would also hinder any future largescale mining operations, using standard methods such as dredging. The feasibility of taking advantage of active processes in the surfzone environment should be investigated to guide in the design of better mining methods.

Beach material is constantly being shifted by combined surf action and littoral drift, which in the area of investigation is predominantly to the west. The movement and winnowing of sediment take place primarily inside the surf zone along the beach foreshore but also in the offshore zone possibly to considerable depth in this high-energy environment. For example, very well-sorted sand extends to a depth of about $50 \mathrm{~m}$ (165 ft) off the Copper River Delta (Reimnitz, 1966).

The winnowing and sorting of light- and heavy-mineral fractions are affected by the interplay of such factors as wave regime, shoreline configuration, and bottom topography in a complex manner which still is not well understood. Local obstruction to littoral drift may block the movement of fine gold, causing it to accumulate in places (Nelson and Hopkins, 1969), but this does not appear to be a general rule. Previous detailed sampling in the Yakataga region showed that gold contents of beach deposits are high for many kilometres east of Cape Yakataga but become low immediately west of the cape (Thomas and Berryhill, 1962). Here the rocky promontory and shallow reef extending for some distance offshore may stop the movement of most of the gold, which is very fine. The gold content in the material moved westward by littoral drift, however, may also become masked by sediment influx from sources west of the cape. There is a third possiblity, namely that Cape Yakataga and its submerged seaward extension deflect the littoral transport, including gold and other valuable minerals, offshore to such depth or location with respect to the wave pattern that it is lost to the littoral drift system. ${ }^{1}$ Along retreating coasts with narrow beaches there probably is a slow net loss of beach material by shoreface erosion. This appears to be true for the Yakataga area. Superimposed on this slow transfer of beach material is the temporary loss of all beach material during storms. Commonly gold and other heavy minerals are moved out along with the general beach material during these events (Charlie Bilderback,

\footnotetext{
1This view is contradictory to results from some studies dealing specifically with transport of sediment in the littoral zone. Such studies, however, have been done only during periods of relatively calm weather when heavy minerals are retained in the nearshore zone.
} 
oral commun., 1969). Whether heavy minerals and gold, in time, again are returned to the beach cycle, and whether any sorting of heavy- and light-mineral fractions takes place in the offshore region under ideal conditions is not known. However, the pattern of beach mining operations along the Gulf of Alaska, where the first activity in one particular area was not more profitable than the last one, indicates that the amount of gold that can be retained in the beach reaches a peak within several decades, and that thereafter gold is lost to the offshore.

The shelf-sampling program carried out in this area by von Huene (oral commun., 1969), shows that in the nearshore sandy-sediment zone, and notably off the areas where modern beaches contain the highest amounts of gold and heavy minerals, heavy-mineral concentrations were up to 47 percent. Samples from this zone also contain small amounts of gold, confirming that gold and heavy minerals are transported offshore today. The shelf-sampling program did not extend into shallow water and did not investigate specific topographically favorable locations where concentrations of heavy minerals might be still greater.

Available evidence from the beaches of the Gulf of Alaska indicates that trace-size gold and heavy-mineral sand are highly mobile in the beach environment, and some part of these may continuously be lost to the beach cycle. In small-scale mining operations, the practice has been to recover gold from local, small, impermanent patches. These operations therefore had to be mobile. Any future large-scale mining operations working the entire beach prism also would have to be mobile, as the beach volume generally is small.

In areas of rapid reworking and sediment transport by marine agencies, as along the Gulf of Alaska coast, it should be possible to set up stationary placer operations. This might be achieved by designing engineering structures to intercept longshore transport. Groins might be used to accumulate and separate sediment in transit along the foreshore or to deflect this material to favorable locations offshore, from which it could be recovered for processing. Studies of existing shore-protection structures in regions where beaches are rich in heavy minerals might indicate types which preferentially bypass or retain light- or heavy-mineral fractions. The harnessing of marine processes to concentrate valuable minerals and gold from materials moving alongshore might enhance the economic potential of some beach placers. Furthermore, the fixed nature of such an operation should reduce its operating cost.

\section{CONCLUSIONS}

Reconnaissance sampling of Gulf of Alaska beaches showed that, in 
general, these beaches have low gold content. Where values are comparatively high, the volume of beach material containing gold is small. Beach placers of the Copper River Delta compare favorably in gold value and heavy-mineral constituents with other areas that have been mined in the past, and there appears to be more dark sand per length of beach in one of the barrier islands than in most other areas. A more detailed study of the Copper River Delta seems to be warranted.

A review of high- and low-resolution seismic profiles from Tarr Bank, on the open continental shelf between Middleton Island and the Copper River Delta, suggests this as a favorable area for future gold exploration. The Yakataga Formation, probable source of much of the placer gold along the shore of the Gulf of Alaska, has been truncated on Tarr Bank and reworked by shallow-water processes. Similar favorable regions may lie on the shelf to the east and west.

Many of the beaches in the area investigated have not accreted over a period of years while the coast retreated; therefore, they are in a state of equilibrium, with supply balanced by loss to offshore areas. Available evidence suggests that gold also is lost to the offshore region. This specific aspect of the dispersal mechanism for fine gold apparently has been little investigated. The difficulty in taking large research vessels nearshore partly accounts for the lack of knowledge concerning gold and heavy-mineral concentrations of modern offshore deposits, especially in high-energy environments. On the other hand, where shelf areas have been explored for heavy-mineral concentrations, such work generally has been limited to the collection of surface samples. Because relict offshore deposits are in deeper water than beaches corresponding in age and therefore commonly are covered by Holocene shelf sediments, they have been neglected in past investigations. These gaps in our knowledge should be filled by suitable studies of possible heavy-mineral concentrations in areas close to, but outside of, the surf zone.

Future studies should also test the feasibility of using fixed engineering structures to concentrate gold or other valuable heavy constituents by the natural forces of the surf-zone environment. Basic background information on this problem could best be obtained in areas more accessible than the Gulf of Alaska.

\section{REFERENCES CITED}

Brooks, A. H., 1913, The mining industry in 1912, in Mineral Resources of Alaska: U.S. Geol. Survey Bull. 542, p. 18-51.

Clifton, H. E., 1968, Gold distribution in surface sediments on the continental shelf off southern Oregon: A preliminary report: U.S. Geol. Survey Circ. 587, 6 p. 
Clifton, H. E., Hunter, R. E., Swanson, F. J., and Phillips, R. L., 1969, Sample size and meaningful gold analysis: U.S. Geol. Survey Prof. Paper 625-C, p. C1-C17.

Cobb, E. H., 1972, Placer deposits of Alaska: U.S. Geol. Survey open-file report, 132 p.

Cook, D. J., 1969, Heavy minerals in Alaskan beach sand deposits: Alaska Univ. Mineral Industry Research Lab. Rept. 20, 114 p.

Kulm, L. D., Heinrichs, D. F., Buehrig, R. M., and Chambers, D. M., 1968, Evidence for possible placer accumulations on the southern Oregon continental shelf: Ore Bin, v. 30 , no. 5 , p. $81-104$.

MacKevett, E. M., Jr., and Plafker, George, 1970, Geochemical and geophysical reconnaissance of parts of the Yakutat and Mount Saint Elias quadrangles, Alaska: U.S. Geol. Survey Bull. 1312-L, p. 1-12.

Maddren, A. G., 1914, Mineral deposits of the Yakataga district: U.S. Geol. Survey Bull. 592, p. 119-153.

1919, The beach placers of the west coast of Kodiak Island, Alaska: U.S. Geol. Survey Bull. 692, p. 313-316.

Miller, D. J., 1953, Preliminary geologic map of Tertiary rocks in the southeastern part of the Lituya district, Alaska. Correlated columnar sections of Tertiary rocks in the Lituya district, Alaska: U.S. Geol. Survey open-file map.

1961a, Stratigraphic occurrence of Lituyapectin in Alaska: U.S. Geol. Survey Prof. Paper 354-K, p. K241-K249.

-1961b, Geology of the Katalla district, Gulf of Alaska Tertiary province, Alaska: U.S. Geol. Survey open-file map.

_ 1961c, Geology of the Yakataga district, Gulf of Alaska Tertiary province, Alaska: U.S. Geol. Survey open-file map.

-1961d, Geology of the Malaspina district, Gulf of Alaska Tertiary province, Alaska: U.S. Geol. Survey open-file map.

1961e, Geology of the Yakutat district, Gulf of Alaska Tertiary province, Alaska: U.S. Geol. Survey open-file map.

Moffit, F. H., 1954, Geology of the Prince William Sound region, Alaska: U.S. Geol. Survey Bull. 989-E, p. E225-E310.

Moore, G. W., and Silver, E. A., 1968, Gold distribution on the sea floor off the Klamath Mountains, California: U.S. Geol. Survey Circ. 605, 9 p.

Moxham, R. M., 1952, Radioactive pegmatite minerals in the Yakataga beach placers, in Moxham, R. M., and Nelson, A. E., Reconnaissance for radioactive deposits in south-central Alaska, 1947-49: U.S. Geol. Survey Circ. 184, pt. 3, p. 11-14.

Nelson, C. H., and Hopkins, D. M., 1969, Sedimentary processes and distribution of particulate gold in northern Bering Sea: U.S. Geol. Survey open-file report, $50 \mathrm{p}$.

Plafker, George, 1967, Geologic map of the Gulf of Alaska Tertiary province, Alaska: U.S. Geol. Survey Misc. Geol. Inv. Map I-484.

1971, Pacific margin Tertiary basin, in Future petroleum provinces of North America: Am. Assoc. Petroleum Geologists Mem., p. 120-135.

Plafker, George, and MacKevett, E. M., Jr., 1970, Mafic and ultramafic rocks from a layered pluton at Mount Fairweather, Alaska, in Geological Survey research 1970: U.S. Geol. Survey Prof. Paper 700-B, p. B21-B26.

Reimnitz, Erk, 1966, Late Quaternary history and sedimentation of the Copper River Delta and vicinity, Alaska: Univ. of California, San Diego, unpub. Ph.D. thesis, $160 \mathrm{p}$.

Reimnitz, Erk, von Huene, Roland, and Wright, F. F., 1970, Detrital gold and sediments in Nuka Bay, Alaska, in Geological Survey research 1970: U.S. Geol. Survey Prof. Paper 700-C, p. C35-C42.

Tarr, R. S., and Butler, B. S., 1909, The Yakutat Bay region, Alaska: U.S. Geol. Survey Prof. Paper 64, 183 p. 
Thomas, B. I., and Berryhill, R. V., 1962, Reconnaissance studies of Alaskan beach sands, eastern Gulf of Alaska: U.S. Bur. Mines Rept. Inv. 5986, 40 p.

Wright, F. F., 1969, Sedimentation and gold distribution, Yakutat Bay, Alaska: Univ. of Alaska, Inst. of Marine Sci., Rept. R69-9, 12 p. 